\title{
KULEUVEN
}

School assessment policy and practice in Belgian secondary education with specific reference to vocational education and training

The final publication is available at http://www.ingentaconnect.com/content/routledg/caie/2005/00000012/00000003/art00004

VERHOEVEN, J. C. \& G. DEVOS (2005) "School assessment policy and practice in Belgian secondary education with specific reference to vocational education and training " Assessment in Education: Principles, Policy \& Practice, 12 (3) pp. 255-274 

School assessment policy and practice in Belgian secondary education with specific reference to vocational education and training

Jef C. Verhoeven

Centre for Sociology of Education

University of Leuven

E. Van Evenstraat 2b

3000 Leuven

Belgium

Geert Devos

Vlerick Leuven Ghent Management School

Reep 1

9000 Ghent

Belgium 


\section{School assessment policy and practice in Belgian secondary education with special reference to vocational education and training ${ }^{1}$}

1. Introduction

Important changes have occurred in the last decade in the Flemish educational system in general and especially in secondary education. Providing training in specific subjects was no longer seen as sufficient for the future of the students because, in addition to cognitive capacities, students also need meta-cognitive, social, and affective skills to function as adults in society. This suggests that schools should be no longer predominantly teaching-oriented but rather student-oriented. At the same time, the government wanted to give more autonomy to the individual school, but policy makers feared that this could lead to standards being lowered. In order to preserve basic standards, therefore, the Flemish government established attainment targets and developmental objectives and introduced a clear distinction between evaluation by means of monitoring of the educational system by the Inspectorate and supporting

\footnotetext{
${ }^{1}$ The authors used gratefully the comments on an earlier draft of this paper made by Dr. Kathryn Ecclestone (University of Exeter, UK) and anonymous referees.
} 
the schools by means of newly established, network-related ${ }^{2}$ pedagogical support services.

Attainment targets and developmental objectives are characterised by teaching content linked to expectations of pupil behaviour in response to this content. The attainment targets and developmental objectives are the minimum objectives that the educational authorities consider to be achievable by most of the students. The objectives function exclusively as an evaluation instrument for the authorities as regards the educational system. Nevertheless, for the students, certification by the class council is based on the attainment of the curriculum objectives provided by a school, not on the basis of the attainment targets and developmental objectives that were integrated into the new type of approved curricula.

In ordinary secondary education, a similar distinction is made between subject-related attainment targets and cross-curricular attainment targets, the latter concerning, for example, learning attitudes, social skills, citizenship, health, and the environment and only have to be aimed for, which is also true for the subject-related attainment targets regarding attitudes. These attainment targets also refer to the attainment targets to be developed for determining the fundamental options and characteristics

\footnotetext{
${ }^{2}$ In Belgium, schools are organized in three networks: schools established by the state, schools established by the cities, and schools established by independent bodies.
} 
of the branch of study that students choose at the $2^{\text {nd }}$ and $3^{\text {rd }}$ stage of secondary education (we discuss this issue below) (Verhoeven \& Dom, 2001).

Even when these attainment targets are not seen as the basis for assessing students, it may be expected that they will influence assessment practices in schools because attainment targets are intended to be a substantial part of the curriculum of all of the schools. Moreover, since these attainment targets stress student-oriented behaviour in schools, it might well be expected that teachers would also develop more student-oriented assessment practices.

The purpose of this paper is thus to describe the relationship between assessment practices and assessment policy and between the general policy and the assessment policy of the school as teachers experience it on a day-to-day basis. Since we know that the attainment targets for general, technical, and vocational education differ, our research needed to explore whether teachers in the three forms of secondary education define these relationships differently. Moreover, because general or technical subjects or practical lessons might be taught in function of different ways of transfer, we also expect teachers to interpret these relations in function of the different types of subject. 
In order to understand better the working conditions of teachers in different forms of ordinary secondary education, we will outline some general characteristics of these different forms. The general framework or 'unified structure' for secondary education comprises three stages of two years each (see Figure 1). The first stage has a common curriculum for most of the students (Verhoeven \& Dom, 2001: 89- 104). This core curriculum is offered in the $1 \mathrm{~A}$ group for those who have obtained the Certificate of Basic Education, but not for those in the 1B group. Without the certificate of basic education, students may be admitted into $1^{\text {st }}$ year $B$. The same holds true for some students who, if their parents consent and if recommended by the Centre for Educational Guidance, do not seem to have the prerequisites for following the 1st year $A$, even though they have obtained the Certificate of Basic Education.

(Figure 1 here)

The second and third stages each comprise three different forms:

- General Secondary Education (Algemeen Secundair Onderwijs: ASO): A broad theoretical training is emphasised here, and it is intended to provide a strong basis for higher education.

- Technical Secondary Education (Technisch Secundair Onderwijs: TSO): The concern is mainly general and technical theoretical subjects. TSO prepares the students for professional life or higher technical education. Practical courses are also included in the training. 
- Vocational Secondary Education (Beroepssecundair Onderwijs: BSO): In this form, students acquire specific skills and simultaneously receive general education. Access to higher education is possible but rare. In full-time vocational secondary education, one may find not only young people gifted with practical minds who wish to learn a trade but also those whose previous school career, sometimes from the primary school onwards, has been marked by a series of failures or learning difficulties.

The efforts to reform vocational education are based on three objectives:

- to prepare the students for an integrated social life;

- to teach the students a trade as realistically and concretely as possible;

- to give the students the type of education that will help them to develop their personality and allow them to become active and responsible members of adult society.

Each stage consists of two years of studies and forms a unit of itself. At the end of the third stage of general academic and technical secondary education, the students may be awarded the Diploma of Secondary Education. On completion of the special $7^{\text {th }}$ year of vocational education, they may also obtain the officially recognised Diploma of Secondary Education. 
The results of the Flemish students on PISA 2000 (OECD Programme for International Student Assessment 2002) reflect characteristics of the students within these three forms of education. Although the mean scores of Flemish students for reading literacy ( $3^{\text {rd }}$ position among 32 countries), mathematical literacy $\left(3^{\text {rd }}\right.$ position $)$, and scientific literacy $\left(9^{\text {th }}\right.$ position $)$ were quite high, there are differences between the scores of the students of the different forms of education. For reading literacy, $78 \%$ of the students in general education attained Level 4 and 5 (the highest level), while only $35 \%$ of students in technical education and $4 \%$ of the students in vocational education attained this level (none of them attained the $5^{\text {th }}$ level). Almost the same pattern can be seen for mathematical and scientific literacy. Nevertheless, although the difference between general education students and technical education students for both of these forms of literacy is smaller, there is still a large difference between students of technical education and students of vocational education (De Meyer et al., 2002).

First, we will explain the major concepts of, and the theory behind, our study. After the presentation of the research questions and methods, we will focus on the relationship between the assessment policy and the assessment practice of the school in Section 4 and, in Section 5, on the relationship between the general policy and the assessment policy of the school. In the last section, we will discuss the results and draw our conclusions. 
2. Conceptual framework

Assessment

Assessment has many facets and many definitions in the literature. In this paper, we see assessment as the collection and interpretation of data about the teaching-learning process (related to the educational targets) in order to measure the progress of the students or to form a basis for making decisions about the progress of the teaching-learning process (Janssens, 1988: 4; De Block \& Heene, 1997: 325; Standaert \& Troch, 1998: 227-228). Defined this way, it is a process that focuses not only on the knowledge of the students but also on their comprehension of the curriculum, their skills, and their attitudes. Moreover, assessment not only is confined to measuring performance but also includes remedies and student guidance. The purpose of this article is to cover these various aspects of assessment. ${ }^{3}$

Assessment also has many functions, some of which conflict with each other. Broadly speaking, the purpose can be formative and an

\footnotetext{
${ }^{3}$ For an ample description of the research results, see Verhoeven et al., 2001.
} 
integral part of learning, or summative as a public confirmation of skills, knowledge, and attitudes. Three are particularly important. First, assessment helps to put the student in the teaching group that best fits them and also helps to determine the appropriate learning path according to the student's capacities and interest. This assessment can be based on summative results from the previous stage or on some form of formative diagnosis. Second, assessment may support the guidance of the teachinglearning process by, for example, enabling the teacher to identify the students who have problems in learning the various parts of the curriculum and to assess his or her own ability to transfer the curriculum. Third, assessment may be seen purely as a diagnostic tool with the object of finding remedies (Verloop \& Zwarts: 1987:226; Janssens, 1988: 5-9; Alberts et al., 1990: 61-68). In this study, we determined which functions are mainly supported by the teachers.

Since assessment is a process, it is also important to look at its different phases. Many authors (e.g. Janssens, 1988; Tistaert, 1993; Standaert \& Troch, 1998; Struyf et al. 1999c) distinguish the following phases in assessment. The first phase is the preparation of the assessment, and the next is the collection of data in function of the criteria collected in the first. In the third phase, the data are analyzed and interpreted, and the fourth consists of the discussion of the findings with the students, the feeding back, as it were, of the results. The last phase 
involves the delivery of a report on student's results to the student, to his or her parents, and to one's colleagues. ${ }^{4}$

School assessment policy

Assessment is the responsibility not only of the individual teacher but also of the school, and schools may well have different opinions about the appropriate assessment procedures. Indeed, these opinions have changed over the last decade. A number of researchers (Schwager \& Carlson, 1994; Kleinsasser, 1995; Birenbaum, 1996; Simpson \& Hayward, 1998; Struyf et al., 1999a; Glaser, 1990) have detected a paradigm shift in assessment: in recent years, teachers and schools have been changing from a testing culture to an assessment culture, at least to a certain extent. Using an ideal typical approach of these two paradigms, one can depict them as follows. We summarize their main characteristics in Table I.

(Table I about here)

\footnotetext{
${ }^{4}$ Because of the size restrictions in this article we cannot describe these different phases.
} 
The testing culture is dominated by the summative type of assessment, the purpose of which is to give a final assessment of the learning achievement of a student over a specific period of time. On the basis of summative assessment, a teacher assesses the 'quality' of what a student has learned (Struyf et al., 1999c; Simpson \& Hayward, 1998).

The assessment culture concentrates on formative assessment with the purpose of improving the learning process of the students and also of raising the quality of the teaching. Formative assessment is interested in discerning the kind of knowledge the student lacks in order to attain his purposes, and the way a teacher can provide the additional information necessary to improve the student's learning process (Struyf et al., 1999; Simpson \& Hayward, 1998).

Although the two paradigms seem to take opposite stances, daily assessment is situated somewhere between these two extremes. It should also be stressed that the development from a testing culture to an assessment culture based on formative purposes depends not only on what the teachers are doing or want to do but also on the attitude of the school leader, the students, and the parents, all of whom need to be more open minded to this other approach of assessment as the school tradition often does not favour it. 
We will describe below if and how close teachers come in their thinking and practice to the assessment culture based on a formative purpose. Nevertheless, since we only questioned the teachers and the heads, ${ }^{5}$ a definitive picture is not possible at this stage because our survey included neither students nor parents.

The general policy and the assessment policy of the school

Since assessment is the responsibility not only of the teacher at the micro level but also of the school as an organisation at the middle level, assessment might be expected to be linked to policy. School policy has two main concerns: organisation and education. In this article, we confine our analysis to the latter since the school's educational policy can take many forms and depends on many factors. We confine our analysis to two types of educational policy, which are not in opposition: a student-oriented policy and an achievement-oriented policy. These two types stress characteristics of education that schools might aim for, and one type of education does not exclude the other in the same school.

\footnotetext{
${ }^{5}$ We will not report on the opinion of the heads in this article.
} 
A student-oriented policy stresses the students as being the main actors in the school. Students are guided in their individual development, and teachers want to make them both responsible for their learning and competent to learn. From this perspective, comprehension and the transfer of the curriculum is more important than the reproduction of knowledge. Students are not transformed into passive participants in the education process but are invited to participate actively. The main targets of assessment are remedy and adapting the teaching to the individual student. A wide spectrum of teaching methods is, therefore, used (Vandenberghe, 1993: 13-14) (Table II).

(Table II about here)

The second type of policy we are interested in is very important for the effectiveness of the school (Scheerens, 1990; Van Petegem, 1997: 32; Scheerens \& Bosker, 1997: 100). This is the achievement-oriented policy. With this policy, the student achievement is seen as the most important purpose of the school. In order to attain this, schools will give space to educational leadership, collective deliberation about the quality of the education among teachers, a quality curriculum, and strong discipline. In the classroom, there will be room for well-structured teaching, high expectations from, and follow-up of, the progress of students, continuous assessment of the students, and reinforcement of successful learning strategies. 
The assessment policy is, therefore, an integral part of the educational and organisational policy of a school. Struyf et al. (1999a: 1) define an assessment policy as the totality of concepts and agreements about how a school wants students to be assessed and about the facilities necessary for assessment (see also Ecclestone, 2002). This policy has different features. First, it is a framework within which decisions might be taken in order to organise the assessment. Second, it is a framework of action for teacher behaviour and a way of legitimising this behaviour within the school. Third, it shows the outside world what a school considers important. Fourth, it is a criterion for evaluating the assessment behaviour of the school, and, if necessary, gives guidelines for improving the system. For there to be a good assessment climate in schools, schools have to have a clear concept of assessment and this concept has to be shared by the entire school team (Janssens, 1988: 20). This means that the collection, interpretation, and registration of assessment data should be as uniform as possible, so that the student's progress can be followed throughout his or her school career.

3. Research methods

The main objectives of this project are: 
- to make an inventory of the main assessment practices and the assessment policy in secondary schools;

- to explore the relationship between the assessment policy and the assessment practice;

- to evaluate the link between the general policy and the assessment policy.

In the present article, we are mainly interested in the last two questions, but we will also provide a short overview of the main assessment practices in Flanders in Belgium. Moreover, we are interested in whether teachers in technical and vocational schools have different experiences of these practices and whether teachers of general or technical subjects or practical-work teachers share opinions about the assessment policy and the other types of school policy.

The research method was partly determined by the demands of the sponsor of our project, ${ }^{6}$ the Flemish Department of Education, which wanted a representative picture of the methods of assessment applied in Flemish secondary schools. In order to form this picture, we choose to conduct a survey by mailing structured questionnaires with some open

\footnotetext{
${ }^{6}$ This article is based on data collected within the framework of a research project financed by the OBPWO (Fund for Educational Policy and Practice-oriented Scientific Research, Brussels) under Contract 99.11.
} 
questions. However, studying assessment practices using this type of questionnaire is not totally free of reliability and validity problems. Indeed, teachers may be prone to offer 'socially desirable' answers. Nevertheless, we felt that it was the most appropriate method for gaining a representative picture of the assessment practices in schools.

In order to create an appropriate research instrument, we first surveyed the literature in depth, and interviewed several teachers and educational experts about assessment practices in schools. Next, we constructed a questionnaire and tested it with 20 teachers who were asked to comment on all the questions in order to determine whether they were easily understandable. They were also asked to suggest corrections. This pilot testing was the basis for the final version of the questionnaire.

The main themes of the questionnaire included the student-oriented policy, the achievement-oriented policy, the assessment policy, the subject-related agreements among teachers concerning assessment, the cross-curricular agreements among teachers concerning assessment, and the agreements between the teachers and the head teacher. We also asked questions about the teachers' own assessment practices, i.e., the assessment techniques and the function of the techniques (summative assessment, remedial action, and guidance). We collected data about the 
preparation of the assessment and the assessment process together with information about the way teachers grade tests, appraise students, and report to students, parents, colleagues, and the head. Scales were constructed for several variables. ${ }^{7}$

\footnotetext{
${ }^{7}$ Information about the scales will be provided in $§ 4$. Assessment policy and assessment practice.
} 
Providing an overview of all the techniques of assessment is not simple because assessment traditions might differ for different subjects. In order to make sure that we would have a representative sample of all the teachers, the sample had to be drawn from the entire population of teachers, taking into account the type of secondary education in our sample and the type of subjects taught. A distinction was made between general and technical subjects and practical lessons. From the teachers teaching a general subject, we chose those who were teaching Dutch, mathematics, or history. The three subjects each have their own particular demands for assessment and bring teachers and students together for a considerable period of time in a classroom each week. The teachers of these subjects may be teaching in one or more of the three forms of education (see Table III). Technical subjects are only taught in technical schools and vocational schools, and the variety of these subjects is greater than among general subjects. We preferred to sample teachers from the largest groups of students in different fields of study in technical schools, 
namely electronics, home economics, and economics. In vocational education, we restricted our sample to those teachers teaching practical lessons in woodworking, metalworking, and home economics.

(Table III about here)

Once the subjects were determined, the teachers were sampled. We selected a stratified sample that took into account the school network and the geographical location of the 200 schools across Flanders. A letter requesting collaboration was sent to the heads of these schools, and 92 heads agreed to participate. A list of teachers provided by the Department of Education made it possible to sample the names of the teachers. We sent questionnaires to 2, 334 teachers. After we sent the questionnaires, a letter to remind the respondents of the survey, and another copy of the questionnaire to the teachers who had not replied within four weeks, we received 1,279 questionnaires back from the teachers (response rate: 
$58.5 \%)^{8}$ and 75 from the heads (response rate: $81.5 \%$ ) from March through May 2000.

What are the main characteristics of the sample? Of the 1,274 teachers who answered the questions, $767(60 \%)$ taught general subjects (Dutch, mathematics, or history), 293 (23\%) taught technical subjects (electronics, home economics, and economics), and 214 (17\%) gave practical lessons (woodwork, metalworking, and home economics). Some $35 \%$ were teaching in general education, $26 \%$ in vocational education, and $39 \%$ in technical education. $47 \%$ of the teachers were male and $53 \%$ female. $21 \%$ were 30 years old or younger, $58 \%$ were between 30 and 50 , and $21 \%$ were 50 or older. $23 \%$ of them has been trained at a university, $56 \%$ in colleges of higher education, and $21 \%$, mainly vocational teachers, has been trained in the courses of Social Advancement Education. 29\% were teaching in the $1^{\text {st }}$ stage (Grades 7 and 8$), 33 \%$ in the $2^{\text {nd }}$ stage (Grades 9 and 10 ), and $38 \%$ in the $3^{\text {rd }}$ stage (Grades 11 and 12 ).

(Table IV about here)

When we compared these figures with the distribution of the teacher population over the different characteristics, we noted in some

\footnotetext{
${ }^{8}$ For this stratified sample the $95 \%$ confidence interval is: \pm 1.96 SE $(S E=2.92)$ for $47 \%$ on the base of the following formula: $\left[\Sigma(p i-p)^{2} / m(m-1)\right]^{1 / 2}$ (Billiet et al., 1990), where $m=$ the number of clusters, $\mathrm{pi}=$ the proportion in each cluster, and $\mathrm{p}=$ the general proportion.
} 
categories quite a large degree of deviation. The largest one is that of the teachers who had obtained their teaching licenses in Social Advancement Education. In order to have a sample large enough to use in our research, we over-sampled these teachers. Moreover, in order to bring the figures to more realistic proportions, we weighted our data with figures calculated on the basis of three combined variables, i.e. the kind of institution where teachers had received their certification (university, college, or social advancement), the stages in which they teach, and the subjects taught. Preliminary calculations showed that these variables are significant for all the kinds of assessment. ${ }^{9}$

\section{Assessment policy and assessment practice}

In this section, we will describe the assessment policy and assessment practice of the schools. The next section will outline the relationship between the general policy and assessment policy of the schools.

\subsection{The assessment policy}

\footnotetext{
${ }^{9}$ It is clear that it is problematic to weight these variables because teachers may teach in different stages, teach subjects of a different type, and teach in general, technical, and vocational tracks at the same time. We did not weight the data on the base of the subjects taught because no information about tracks of education in which the teachers worked combined with the other variables was available.
} 
The assessment policy of a school is defined as 'the collection of ideas and agreements about how the school wants to assess students and about the necessary facilities to fulfil this task'. A Likert-like scale of five items $(\alpha=.67)$ was constructed to gather information about the attitude of the teachers toward the assessment policy. The items were: 'I know the vision of the school about assessment'; 'I back up the vision of the school concerning assessment'; 'there are guidelines in the school for the assessment'; 'there is deliberation among all teachers of the same stage about assessment of students'; and 'the head plays an important role in the system of assessment of the school.'

(Table V about here)

In general, teachers were aware of the assessment policy of their school (score $=3.66$ out of $5 ; s d=1.03$ ). A score of 3.66 may be seen as a moderate attitude toward the assessment policy. Nevertheless, about $83 \%$ of the teachers claimed to know the school's view on assessment. The more the teachers were convinced that there is an assessment policy, the more they experienced deliberation between teachers and the head about the assessment ${ }^{10}(r=.48 ; p<.0001),{ }^{11}$ and the more subject-related

\footnotetext{
${ }^{10}$ This index has 9 items $(\alpha=.88)$ with scores between 1 and 5 .

${ }^{11}$ Pearson correlation coefficient $=r$.
} 
agreements were made between teachers of the same subject ${ }^{12}(r=.48 ; p$ $<.0001)$. Both relations are equally strong in both general $(r=.48$ and .50 , respectively), vocational $(r=.44$ and .49 , respectively), and in technical $(r=$ .49 and .45 , respectively) education. The same relationship can be found between variables among teachers of general and technical subjects, but the relationship among practical-work teachers is a little weaker $(r=.41$ and .38 , respectively).

Teachers of vocational (score $=3.73$ out of 5 ) and general education (score $=3.69$ ) rate the assessment policy slightly higher than teachers in technical education $(\mathrm{score}=3.55)(F(2,1164)=3.96 ; p=$ .027). In addition, the type of subject taught by the teachers makes a difference in their appraisal of the assessment policy: teachers teaching general subjects (score $=3.66$ out of 5 ) and those teaching practical lessons (score $=3.73$ ) value the assessment policy slightly higher than teachers teaching technical subjects $(\mathrm{score}=3.55)(F(2,1265)=9.19 ; \mathrm{p}=$ .0001). When controlled for the subject, the difference between the three forms of education is still present $(F(2,1159)=6.55 ; p=.0001)$ : in technical education, the teachers value the assessment policy less than do than those in vocational education.

\footnotetext{
${ }^{12}$ This index has 9 items $(\alpha=.88)$ with scores between 1 and 5 .
} 
Assessment may be the subject of discussions during meetings of teachers, head, and parents. ${ }^{13}$ The most important meetings in this respect are the class councils (score $=3.2$ out of 4 ) and the teacherparents contacts (score $=3.03$ ). Nevertheless, the general mean of the teachers' opinion about the importance of the different councils and task forces for assessment is rather low (score $=2.5$ out of 4 ; $s d=.5$ ). The frequency of discussions about assessment in meetings is no different among teachers in vocational education with respect to other secondary education teachers $(F(2,1163)=1.75 ; p=.174)$. Neither do teachers of general, technical, and practical lessons differ among each other as far as discussions in meetings about assessment is concerned $(F(2,1264)=$ $0.08 ; p=.93)$

As might be expected, the higher the teachers rate the discussions about assessment, the higher they value that assessment policy $(r=.33 ; p$ $<.0001)$. This relationship is almost the same in three types of education and among the teachers of general or technical subjects and the practicalwork teachers.

4.2. Assessment practice

\footnotetext{
${ }^{13}$ This index has 11 items $(\alpha=.85)$ with scores between 1 and 4.
} 
There is a clear relationship between the type of summative assessment instruments that teachers use and their subject. For example, teachers of Dutch, mathematics, and history use more traditional written assessment instruments (e.g. written tests and exams, home work, informal observation) than do teachers of technical subjects and practical lessons $(p<.0001)$. Teachers teaching practical work use instruments of continuous assessment and self-assessment by the students $(p<.0001)$ more than do other teachers, and, together with teachers of technical subjects they use more demonstration and/or presentations than do teachers of general subjects $(p<.0001)$. This is likely to be because such types of assessment instruments are inherent to the kind of knowledge and skills taught in practical work. In contrast, teachers in general and technical education use more written assessment techniques, while teachers in vocational schools prefer much more demonstration, permanent assessment, and self-assessment.

The frequency of the written tests is significantly higher in general education (score $=3.9$ out of 5$)$ than in technical $($ score $=3.0)$ and vocational $($ score $=2.7)$ education $(F(2,1146)=27.55 ; p<.0001)$. Teachers of general subjects (score $=3.4$ out of 5 ) also test more frequently than do technical (score $=2.9$ ) and practical-work teachers $($ score $=2.4)$ do $(F(2,1243)=69.63 ; p<.0001)$. 
Continuous assessment is practised more by teachers in vocational education (score $=3.6$ out of 5 ) than by teachers in general and technical education $($ score of both $=2.8)(F(2,1095)=14.35 ; p<.0001)$. Practicalwork teachers (score $=3.7$ ) more frequently apply permanent assessment than do general $($ score $=2.8)$ and technical $($ score $=3)$ teachers $(F(2$, $1187 ; 19.94 ; p<.0001)$

According to the teachers, the main function of assessment is to measure ${ }^{14}$ the knowledge of the subject matter by the students (score = 4.33 out of 5$)$; the second function is to collect information in order to provide guidance ${ }^{15}$ to the students (score $=4$ out of 5 ); and the third is to prepare remedial action ${ }^{16}($ score $=3.6$ out of 5$)$. Teachers in general education (score $=4.4$ out of 5 ) stress more the summative function of assessment than do teachers in technical (score $=4.3$ ) and in vocational (score $=4.1$ ) education, and teachers of vocational education do it less than the two other categories $(F(2,1264)=15.22 ; p<.0001)$. This summative function is rated differently by teachers of the different subjects $(F(2,1266)=3.42 ; p=.03)$, but the Tukey test shows no differences. The remedial function of assessment is more important according to practicalwork teachers (score $=3.7$ out of 5 ) than according to teachers of general

\footnotetext{
${ }^{14}$ This index is composed of 4 items $(\alpha=.74)$ with scores between 1 and 5 .

${ }^{15}$ This index is composed of 4 items $(\alpha=.71)$ with scores between 1 and 5 .

${ }^{16}$ This index is composed of 3 items $(\alpha=.68)$ with scores between 1 and 5 .
} 
subjects (score $=3.5)(F(2,1266)=3.72 ; p=.02)$, but there is no difference in appreciation of this function among teachers of the different types of education $(F(2,1164)=1.92 ; p=.14)$. The average rating of the guidance function of assessment is alike in all forms of education ( $F(2$, $1163)=1.17 ; p=.31)$ and among the teachers of the three types of subjects $(F(2,1265)=1.40 ; p=.64)$.

What do teachers want to assess when they assess students? In order to answer this question, we asked the teachers questions about the kind of knowledge (2 items), comprehension ( 2 items), skills (3 items), and attitudes (4 items) they expect students should attain. In Table VI, we find the answers for each of the items.

(Table VI here)

One of the big problems with questions of this type is the tendency among respondents to give socially-desirable answers. One way to solve this problem is through observation, but this could not be organised within this project.

Nevertheless, even if these figures may be socially biased, they give an interesting picture of teachers' day-to-day practices. Only one third of the teachers want the students to reproduce the course literally, but $71 \%$ expect knowledge of facts and concepts. About $83 \%$ of the teachers stress that they want to know whether the students can work accurately, and the same proportion wants the students to be 
able to see links between the various parts of the course. Even when the majority of the teachers (80\%) think that attitudes should be assessed, they (84\%) admit that it is difficult to do so.

As far as the assessment of knowledge of facts and concepts is concerned, we found differences between teachers of different types of education $(F(2,1156)$ $=5.47 ; \mathrm{p}=.004)$. The teachers of general education $($ score $=2.95)$ scored higher than teachers of vocational (2.87) and technical education (2.89), but no difference emerged between the different types of subjects $(\mathrm{F}(2,1256=.43 ; \mathrm{p}=$ $.65)$.

More differences were found. Practical-work teachers pay more attention to the accuracy of students' work $($ score $=3.6$ out of $4 ; \mathrm{F}(2,1260)=37.02$; $\mathrm{p}<.0001$ ) and the students' level of independence in solving problems (score = $3.4 ; \mathrm{F}(2,1161)=14.57 ; \mathrm{p}<.0001)$ than do teachers of technical $($ score $=3.2$ and 3.1, respectively) and general subjects (score $=3.1$ and 3.2, respectively). Teachers in vocational education $($ score $=3.4$ ) also pay attention more often to the accuracy of students' work than do teachers of general (score $=3.2$ ) or technical $($ score $=3.1)$ education $(F(2,1160)=10.73 ; \mathrm{p}<.0001)$, which is not the case for the students' level of independence in solving problems $(F(2,1244)=.63 ; \mathrm{p}=.53)$. Teachers in general education value more the principle of looking at the links that students make $($ score $=3.2$ out of $4 ; \mathrm{F}(2,1150=24.32 ; \mathrm{p}=.0001)$, their application of theory ( score $=3$ out of $4 ; \mathrm{F}(2,1157=9.88 ; \mathrm{p}<=.0001)$, and their capacity for critical reasoning $($ score $=2.8$ out of $4 ; \mathrm{F}(2,1154)=15.99 ; \mathrm{p}<.0001)$ 
than do teachers in vocational education ( $\operatorname{score}=2.9 ; 2.8$ and 2.6, respectively). Moreover, we see that teachers teaching general subjects $($ score $=3.1)$ pay attention more often to the principle of looking at the links that students make $(\mathrm{F}(2,1250=5.07 ; \mathrm{p}=.006)$ and their capacity for critical reasoning $($ score $=2.8$; $\mathrm{F}(2,1253=10.31 ; \mathrm{p}<.0001)$ than do practical-work teachers (respectively score $=$ 2.9 and 2.6).

Accuracy in work $($ score $=3.6 ;(\mathrm{F}(2,1260=37.02 ; \mathrm{p}<.0001)$ and systematic work of students $($ score $=2.9(\mathrm{~F}(2,1248)=6.31 ; \mathrm{p}=.002)$ is more frequently assessed by teachers in vocational education than by teachers in general education (score $=3.1$ and 2.8, respectively) and teachers in technical education (score $=3.2$ and 2.9, respectively). Independence in answering the questions takes the same pattern: teachers in vocational schools $($ score $=3.01)(\mathrm{F}(2,1158)=$ $16.83 ; \mathrm{p}<.0001)$ assess this characteristic more frequently than do teachers in technical $($ score $=2.8)$ and general education $($ score $=2.6)$. Moreover, practicalwork teachers $($ score $=3.1)$ score significantly higher on this target than do technical $($ score $=2.9)$ and general teachers $($ score 2.6$)(F(2,1257)=28.09 ; \mathrm{p}$ $<.0001)$

To what extent do teachers take into account skills and attitudes ${ }^{17}$ when they assess students? On a scale of 1 to 4 , teachers score 2.75 , which is only a little higher than the midpoint. Skills and attitudes, while seen as important in assessment, are not the main interest of teachers - teachers still internalise the

\footnotetext{
${ }^{17}$ This index is composed of 10 items $(\alpha=.77)$ with scores between 1 ad 4 .
} 
values and activities of a testing culture. Opinion about these skills and attitudes in general does not differ between technical and vocational education $(\mathrm{F}(2,1165)$ $=1.66 ; \mathrm{p}=.19)$. However, the data shows that practical-work teachers (score $=$ 2.8 out of 4 ) and technical teachers (score $=2.8$ ) pay significantly more attention to skills and attitudes than do teachers of general subjects $($ score $=2.7)(\mathrm{F}(2$, $1266)=5.77 ; p=.003)$, and this relationship is kept under control for the educational track $(\mathrm{F}(2,1163)=11.22 ; \mathrm{p}<.0001)$.

Of course, assessment is not only a product but also a process. Teachers and students pass through a process while testing is going on (8 items), when the teacher appraises the students ( 2 items), and during the feedback process after the test $(6$ items $){ }^{18}$ The average score is 2.57 out of $4(\mathrm{sd}=.41)$, which means that a process-oriented approach in the assessment process is situated somewhere between 'sometimes' and 'often'. This process-oriented approach belongs more to the pattern of behaviour of the practical-work teacher (score $=2.7$ out of 4$)(\mathrm{F}$ $(2,1265)=9.11 ; \mathrm{p}<.0001)$ than of the teacher of general $($ score $=2.6)$ and technical subjects (score $=2.5$ ). The same can be said about the assessment behaviour of teachers in vocational (score $=2.6$ ) or general education (score $=$ 2.6) in comparison with teachers in technical education (score $=2.5)(\mathrm{F}(2,1164)$ $=6.49 ; \mathrm{p}=.002)$. It is important to know that the difference between the three types of subjects remains even when we control for the type of education ( $\mathrm{F}$ $(2,1162)=6.76 ; \mathrm{p}=.002)$.

\footnotetext{
${ }^{18}$ This index is composed of 16 items $(\alpha=.73)$ with scores between 1 and 4 . Some examples of items used in this scale: During a test I check whether the students understand the questions; students may ask questions during a test; in order to motivate the students; I comment the results of the test; homework is discussed in the classroom.
} 
Most of the teachers consider homework $($ score $=1.6$ out of $4 ; \mathrm{SD}=.64)$ and exams ( score $=1.1 ; \mathrm{SD}=.45$ ) as a task that has to be performed individually by the student. Collaboration among students during tests is rarely permitted. In spite of these strict principles, there is a difference between teachers of different types of education $(\mathrm{F}(2,1146)=4.03 ; \mathrm{p}=.0181)$. Teachers in vocational education (score 1.63) allow more collaboration in homework than do teachers of technical $($ score $=1.5)$ or general $($ score $=1.5)$ education, while practical-work teachers support this $($ score $=1.65)$ more than do teachers of general subjects $($ score $=1.5)$ $(\mathrm{F}(2,1245)=3.43 ; \mathrm{p}=.03)$. For exams, we see the same pattern among teachers of different types of education $(\mathrm{F}(2,1081)=7.43 ; \mathrm{p}=.0006)$ with teachers of vocational education having the highest score (1.23), which is still very low. This is also the case for the different subjects $(\mathrm{F}(2,1175)=9.79 ; \mathrm{p}<.0001)$ where, again, the highest score was for practical-work teachers (1.3), and the lowest for general subject teachers $($ score $=1.1)$.

When teachers report the outcomes of tests or exams to students and parents, they sometimes use a figure $(32 \%)$ or a figure with a short comment (64\%), and about $4 \%$ use other forms (i.e. a letter, a detailed comment or an oral assessment). Most of the teachers (66\%) favour a report with figures while $11 \%$ reject it. No more than $54 \%$ of the teachers are positive towards a report that uses only comments. Teachers of technical and general education (score $=3.4$ and 3.5 out of 5, respectively) are less positive about a report that is composed only of comments than are teachers in vocational education $($ score $=3.6)(F(2.1136)=$ 
$11.21 ; \mathrm{p}<.0001)$. Practical-work teachers $($ score $=3.6)$ are also more positive towards a report consisting of comments than are teachers of technical subjects (score 3.4) $(\mathrm{p}=.04)$. Nevertheless, the opinion of the teachers of different subjects concerning this issue is almost the same $(\mathrm{F}(2,1230)=2.88 ; \mathrm{p}=.06)$

After the summative assessment, $61 \%$ of the teachers give extra guidance to the students, $26 \%$ give individual assignments, and $60 \%$ test the same subject matter again. Between the different types of education and subjects, we did not observe many differences except for those teachers who give extra guidance or individual assignments. Teachers in general (score $=3.7$ ) and technical education $($ score $=3.6) ; \mathrm{F}(2,1147)=5.11 ; \mathrm{p}=.006)$, and those who teach technical subjects $($ score $=3.7 ; \mathrm{F}(2,1244)=3.69 ; \mathrm{p}=.03)$ score higher than do teachers in vocational education (score $=3.5$ ) and practical-work teachers (score 3.6), respectively. Among the teachers who give individual assignments, we see a higher application of this practice only among general education teachers $($ score $=2.9)$ in comparison with technical education teachers $($ score $=2.7 ; \mathrm{F}(2,1148)=3.42 ; \mathrm{p}=$ $.03)$.

5. General policy and assessment policy

The last question we want to address concerns the relationship between the general policy and the assessment policy. In the general policy, we highlighted a 
difference between a student-oriented policy ${ }^{19}$ and an achievement-oriented policy. ${ }^{20}$ It should be stressed that a school might implement a student-oriented as well as an achievement-oriented policy. In Flanders, the teachers reported that their schools apply a student-oriented policy ( $\operatorname{score}=3.58$ out of $5 ; \mathrm{sd}=.56$ ) more than an achievement-oriented policy (score $=3.28$ out of $5 ; \mathrm{sd}=.62)(\mathrm{t}=13.621$; $\mathrm{p}<.0001$ ), and there is only a weak relationship between the opinions of teachers stressing a student-oriented policy and those stressing an achievement-oriented policy $(\mathrm{r}=.058)$.

Variance analysis shows that teachers in technical education experience a significantly lower level of student-oriented policy (score $=3.5$ out of 5$)$ than do teachers in vocational $($ score $=3.6)$ and general $($ score $=3.6)$ education $(\mathrm{F}(2$, $1164)=3.96 ; \mathrm{p}=.02$ ). This relationship disappears when we control for type of subject $(\mathrm{F}(4,1162)=1.88 ; \mathrm{p}=.154)$. In a similar vein, we can say that teachers of technical subjects (score $=3.5$ ) score lower on student-oriented policy than other teachers $($ score $=3.6)(\mathrm{F}(2,1266)=4.74 ; \mathrm{p}=.008)$, but this relationship disappears after controlling for the type of education $(\mathrm{F}(2,1162)=2.22 ; \mathrm{p}=.10)$.

Teachers in general education scored highly on student-oriented policy and also $($ score $=3.4$ out of 5$)$ significantly higher than teachers in technical $($ score $=$

\footnotetext{
${ }^{19}$ This index is composed of 11 items $(\alpha=.81)$ with scores between 1 and 5 . Some examples of items: 'in my school the staff is very concerned about differentiation of the subject matter'; 'in my school the guidance is strong for learning students how to learn'; 'in my school much effort is invested in guiding the weak students'; etc.

${ }^{20}$ This index is composed of 9 items $(\alpha=.84)$ with scores between 1 and 5 . This scale is constructed by P. Van Petegem (1997: 194). Some examples of items: 'In my school, hard work for each subject is stressed'; 'in my school, the head stimulates achievement oriented education'; 'in my school, teachers are achievement oriented'.
} 
$3.2)$ or in vocational education $($ score $=3.3)(F(2,1164)=12.58 ; \mathrm{p}<.0001)$ as far as achievement-oriented policy is concerned. Practical-work teachers (score = 3.4) score higher in this respect than do the teachers of general (score $=3.2$ ) or technical subjects $($ score $=3.3)(\mathrm{F}(2,1266)=5.9 ; \mathrm{p}=.002)$. Variance analysis shows that these relationships are still present when we control for each of these two independent variables $(\mathrm{F}(4,1162)=22.15 ; \mathrm{p}<.0001)$

If teachers think that the school pursues a student-oriented policy, they also express the conviction that the school develops an assessment policy $(r=.43$; $\mathrm{p}<.0001$ ), but this is less the case when the teachers experience more of an achievement-oriented policy $(\mathrm{r}=.12 ; \mathrm{p}<.0001)$. We found the same relationships among teachers of general education for those who see a studentoriented policy in the school but not for those who experience more of an achievement-oriented policy. In both technical and vocational education teachers experience the same link between student and achievement-oriented policies.

(Table VII about here)

We found similar relations among teachers according to the subject they teach. When the school pursues an achievement-oriented policy, teachers of general subjects are not aware of an assessment policy. This is not the case when the school pursues a student-oriented policy. This result is different for practicalwork teachers and teachers of technical subjects. In addition, those who stress an achievement-oriented policy recognize an assessment policy, but much less than 
those who experience a student-oriented policy. ${ }^{21}$ We may conclude that an assessment policy is better supported by a student-oriented policy than by an achievement-oriented policy. However, among teachers in vocational education and training, this relationship is different: they also see a relationship between the assessment policy and the achievement policy, though this link is significantly weaker.

(Table VIII about here)

When we look at some specific characteristics of the assessment policy, we find similar relationships as before (see Table VIII). In schools where teachers have the impression that there is a student-oriented policy, they believe that their colleagues deliberate among each other and also with the head about assessment. Moreover, in schools where teachers recognise a student-oriented policy, they also have a significant number of meetings concerning assessment. This is less true for teachers who see in their school more an achievement-oriented policy. The same relationships are found among teachers of vocational or technical education, but not among teachers of practical work or technical subjects who see no difference between the relation between student-oriented and achievementoriented policies in relation to deliberations among teachers or deliberation between teachers and the head. Teachers of general education and those teaching

${ }^{21}$ We made grateful use of an SAS macro written by Michel Philippens (KU Leuven) to calculate the difference between sample correlation coefficients drawn from the same correlation (see Table VII and VIII) based on a method described by Cohen \&Cohen (1983: 93). 
general subjects have a different opinion: the three variables are linked with a student-oriented policy but not with an achievement-oriented policy.

\section{Discussion and Conclusion}

Reviewing teachers' attitudes toward assessment policy, it is clear that teachers are not convinced that most schools have a clear concept of an assessment policy. This is the case even though that about $82 \%$ of the teachers claims to know what the vision of the school on assessment is. A mean score of 3.66 out of 5 is not high. A significant number of teachers do not receive guidelines about assessment in the school nor do they participate in discussions about assessment. Nevertheless, if teachers discuss assessment issues and make agreements among themselves within the same subject, they are more aware of an assessment policy. However, there is no difference between different groups of teachers in relation to their judgement about the frequency of discussions of assessment issues in various kinds of school meetings. Whatever the subject and in whatever track teachers teach, the mean score does not vary between the different groups. However, although teachers in vocational education do not experience the assessment policy differently from teachers in general education, teachers in technical education do. Moreover, when we compare practical-work teachers with teachers of general subjects, both categories are equally aware of an assessment policy, and teachers of technical subjects differ from both of the other categories. 
Although the last statement supports the thesis that each type of education or subject forms the basis for a typical school culture, the difference is not present and does not have a special pattern. If we take into account that teachers in technical and vocational education are working with youngsters who have more interest in technical and manual subjects, then it could be expected that there is a reasonable chance for teachers of technical and vocational education to share the same ideas about assessment. However, in our research, the facts deny this expectation. Teachers in vocational education are closer to teachers in general education as far as their opinion about the assessment policy is concerned than to teachers in technical education. Moreover, practicalwork teachers (and they only teach in vocational education) seem to be closer in this respect to teachers of Dutch, mathematics, or history than to teachers of technical subjects.

In the light of this view of assessment policy, we wondered if we could see the same pattern in the different parts of the assessment process. It is not easy to form a comprehensive picture of assessment behaviour amongst the teachers in the different forms of education and those teaching various types of subjects. The most uncertain position is that of teachers in technical education. Sometimes they lean towards the teachers in general education, sometimes they are closer to the teacher in 
vocational education. But, contrary to the opinion about assessment policy, teachers of vocational education very seldom follow the pattern of teachers of general education.

In comparison with teachers of general education, teachers of vocational education may be typified as preferring fewer traditional written assessment instruments (e.g. written tests and exams, home work). They prefer instruments of continuous assessment or self-assessment by students. Moreover, they also more often choose demonstrations and presentations to serve as assessment instruments.

In relation to the other teachers, those in vocational education are more likely to regard assessment as an instrument to detect the remedy that the student needs in order to improve. They see it as a means of determining the level of knowledge. In spite of these differences, the main function of assessment for teachers in vocational education is to check knowledge (score $=4.3$ out of 5 ); the second function is to use assessment as part of the guidance of students (score $=4.2$ ); and the third is to use assessment as an instrument to tell the students what they know $($ score $=3.8)$. 
Asked about the assessment targets, the teachers of vocational education value the assessment of knowledge a little lower than do the other teachers, and they are less interested in students' capacity to see the links between parts of the curriculum, theory, and critical reasoning. Indeed, vocational education aims primarily at the transfer of specific skills in addition to offering a general education. Nevertheless, this special training makes teachers in vocational education more interested in the accuracy of students' work.

This typification of the teacher in vocational education is mostly supported by the picture we were able to collect when taking only the practical-work teachers into account. All these teachers work in vocational education, but this group has no teachers of general subjects in vocational education. This overview enables us to argue that teachers in vocational education appear to have developed a different kind of assessment culture from the others.

This raises another question: Do teachers in Flanders appear to support an assessment culture or do they conform to the testing culture (Birenbaum, 1996; Struyf et al., 1999b; Glaser, 1990; Kleinsasser, 1995)? The main characteristics of the assessment process lead us to conclude that teachers still live in the testing culture. Only $17 \%$ of the teachers assess the students by frequently applying a kind of process approach to 
assessment. In vocational education, this approach is more popular among the practical-work teachers than it is among the teachers in the other educational tracks. Assessment is still mainly seen as an instrument to rate students and less for guidance or remedy. Assessment is predominantly practised in relation to the work of individuals. Collaboration by students during assessment is not allowed because the main target is the rating and grading of students. Alternative forms of assessment ${ }^{22}$ are hardly mentioned (by only $17 \%$ of the teachers), and we gather that they do not often apply these methods. Most of the teachers report to parents and students by figures and a short comment, but not all of the teachers provide feedback after a test or exam. In view of all these phenomena, there are not many indications of an assessment culture among the teachers. Although teachers in vocational education sometimes take the direction of the assessment culture, most of them also still live predominantly in the testing culture.

Although the testing culture exerts a very strong influence over schools in Flanders, the school policy shows an opening towards an assessment culture, an observation that is also made by Simpson and Hayward (1998: 452-455) in Scotland, although probably more optimistically than we do. However, this is no certainty but a possibility.

\footnotetext{
22 Some examples are: assessment by computer, group work and assessment by the group, book review, talk given by student, open book test, exercises, etc.
} 
Indeed, a student-oriented policy is more present than an achievementoriented policy. This distinction is important because a student-oriented policy encompasses the differentiation of the subject matter in teaching students how to learn, in guiding the weak students, etc. All these values are close to the principles at the heart of a broad assessment culture. This is not the case with the values encompassed in an achievement-oriented policy. Most of the items in the last variable are about hard work of students, achievement-oriented teaching, etc. Therefore, it could have been expected that teachers who perceive a student-oriented policy in their school also see an assessment policy, but it could also have been expected that teachers who discern an achievement-oriented policy in their school will not be so keen to see an assessment policy.

The question is now whether teachers of vocational education have an opinion about this point that is different from the other teachers. Our study shows that they have but not always in the way we thought. Teachers in vocational education experience more student-oriented policies than teachers of technical education do, but they do not differ from the teachers in general education. As far as achievement-oriented policy is concerned, there is a difference between teachers in vocational schools and the others. Nevertheless, teachers in the three forms of education see equally a relatively strong relationship between a student-oriented policy and the assessment policy, and a weak relationship between an 
achievement-oriented policy and the assessment policy. A studentoriented policy can possibly be a good breeding ground for an assessment policy and an assessment culture geared more to formative assessment. This expectation is confirmed by the conclusion that teachers in favour of student-oriented policy to a certain extent also perceive deliberation among teachers and among teachers and head in their schools about assessment and see that a number of meetings are held in school where assessment is on the agenda. In addition, these correlations have been found among teachers in vocational education as well as among other teachers.

Our analysis has shown that teachers of vocational, technical, and general education have different opinions about assessment practice, assessment policy, student-oriented policy, and achievement-oriented policy. We also argued that a testing culture is still more alive than a broad type of assessment culture and that, in vocational education at least, there are indicators of a possible change in the direction of an assessment culture. Whether this change will occur soon is not easy to determine. We can only hypothesise that if the policy in most schools develops more into the direction of a student-oriented policy then the chance will increase that an assessment culture will emerge. Whether this will happen more rapidly in vocational and technical education is an open question. Our data do not allow us to answer this particular question. 
References

Alberts, R., P. H. de Bok, A. Broeders \& D. Marbus (1990) Leren

Evalueren, een Bundel Cursusmateriaal voor Studenten en

Docenten van de Lerarenopleiding (Arnhem, Cito).

Billiet, J., A. Carton, R. Huys (1990) Onbekend of Onbemind ? (Leuven: Sociologisch Onderzoeksinstituut)

Birenbaum, M. (1996) Assessment 2000: Towards a pluralistic approach to assessment, in M. Birenbaum \& F. Dochy (Eds) Alternatives in Assessment of Achievements, Learning Processes and Prior Knowledge (Boston, Kluwer Academic Publishers).

Cohen, J. \& P. Cohen (1983) Applied Multiple Regression/correlation analysis for Behavioural Sciences. (Hillsdale, N.J.: Lawrence Earlbaum Associates).

De Block, A. \& J. Heene (1997) Inleiding tot de Algemene Didactiek (Antwerp, Standaard Educatieve Uitgeverij).

De Meyer, I., H. De Vos \& L. Van de Poele (2002) Wereldwijd Leren op 15. De Eerste Resultaten van PISA 2000 (Brussels/Ghent, Ministerie van de Vlaamse Gemeenschap/Universiteit Gent, Vakgroep Onderwijskunde).

Ecclestone, K. (2002) Understanding assessment and qualifications in post-16 education: principles, practice and policy. (Leicester, National Institute of Adult and Continuing education).

Glaser, R. (1990) Towards new models for assessment, International Journal of Educational Research, 14, pp. 475-483.

Janssens, F. J. G. (1988) Evaluerend onderwijsgedrag, in Onderwijslexicon (Alphen aan de Rijn/Zaventem, Samsom H.D. Tjeenk Willink).

Kleinsasser, A.M. (1995) Assessment culture and national testing, Clearing House, 68, pp. 205-211.

OECD (2002) Knowledge and Skills for Life. First Results from PISA 2000 (Paris, OECD). 
Scheerens, J. (1989) Wat Maakt Scholen Effectief? Samenvatting en Analyse van Onderzoeksresultaten. ('s Gravenhage, Het Instituut voor Onderzoek van het Onderwijs SVO).

Scheerens, J. (1990) School effectiveness research and the development of process ndicators of school functioning, School Effectiveness and School Improvement, 1, pp.61-80.

Scheerens, J. \& R. Bosker (1997) The Foundations of Educational Effectiveness (London, Pergamon).

Schwager, M.T. \& J.S. Carlson (1994) Building assessment cultures, Education \& Urban Society, 26, pp. 390-404.

Simpson, M. \& L. Hayward (1998) Policy, Research and Classroom-based Development: changing the assessment culture in Scottish schools, European Journal of Education, 33, pp. 445-458.

Standaert, R. \& F. Troch (1998) Leren en Onderwijzen: Inleiding tot de Algemene Didactiek (Leuven, Acco).

Struyf, E., R. Vandenberghe \& W. Lens (1999a) Een beleid voor de evaluatie van leerlingen, in Schoolleiding en -begeleiding (Zaventem, Kluwer Editorial).

Struyf, E., R. Vandenberghe \& W. Lens (1999b) Recente ontwikkelingen in het denken over evaluatie, in Handboek Leerlingenbegeleiding (Zaventem, Kluwer Editorial).

Struyf, E., R. Vandenberghe \& W. Lens (1999c) Het formatieve en summatieve karakter van schriftelijke toetsen, in Handboek Leerlingenbegeleiding (Zaventem, Kluwer Editorial).

Tistaert, G. (1993) Evaluatie in de klas, Nova et Vetera, 1-2, pp. ${ }^{16-37 .}$

Vandenberghe R. (1993) Scholen en Vernieuwing: een Kans tot Professionele Groei en Schoolverbetering (Leuven, Centrum voor onderwijsbeleid en - vernieuwing).

Van Petegem, P. (1997) Scholen op Zoek naar hun Kwaliteit. Effectieve-scholenonderzoek als Inspiratiebron voor de Zelfevaluatie van Scholen (Gent, Universiteit).

Verhoeven, J.C. \& L. Dom (2001) Flemish EURYDICE Report 2000.

Education Policy and Organisation in Flanders (Brussels, 
Ministry of the Flemish Community, Department of Education, Policy Coordination Division).

Verhoeven, J.C., G. Devos, W. Bruylant \& V. Warmoes (2001) Evalueren in Vlaamse Secundaire Scholen: Een Onderzoek bij Leraren en Directeurs (Antwerp - Apeldoorn, Garant). 
Table I: Essential charcteristics of the testing culture and the assessment culture.

\begin{tabular}{|c|c|}
\hline 1.1.1.1.1 Testing culture & Assessment culture \\
\hline $\begin{array}{l}\text { a behaviouristic concept of education; learning is } \\
\text { only the transmission of knowledge }\end{array}$ & $\begin{array}{l}\text { the concept of education is constructivist; } \\
\text { students are seen as active learners and the main } \\
\text { purpose of teaching is not the transfer of } \\
\text { knowledge but rather the imparting of learning } \\
\text { strategies }\end{array}$ \\
\hline $\begin{array}{l}\text { rating is the main function of appraisal } \\
\text { (summative assessment); }\end{array}$ & $\begin{array}{l}\text { the function of appraisal is guiding and reviewing } \\
\text { progress (formative assessment); }\end{array}$ \\
\hline $\begin{array}{l}\text { the purpose is to test the knowledge of the } \\
\text { students; }\end{array}$ & the purpose is to assess skills \\
\hline the main instrument is the written test; & $\begin{array}{l}\text { there is a wide range of instruments and written } \\
\text { tests play only a minor role }\end{array}$ \\
\hline the test assesses an individual & $\begin{array}{l}\text { assessment has to be made between students } \\
\text { and between students and teachers }\end{array}$ \\
\hline $\begin{array}{l}\text { each teacher is individually responsible for the } \\
\text { testing }\end{array}$ & $\begin{array}{l}\text { the responsibility for the assessment is shared by } \\
\text { teachers and students }\end{array}$ \\
\hline students are considered to be passive & the student is seen as an pro-active human being \\
\hline the report is mainly expressed in figures & $\begin{array}{l}\text { the report not only gives figures but also a } \\
\text { description of the student's profile }\end{array}$ \\
\hline $\begin{array}{l}\text { in the process of assessment the test is a } \\
\text { separate phase that is often seen as the end } \\
\text { of a learning process }\end{array}$ & $\begin{array}{l}\text { the process of appraisal is seen as integrated in } \\
\text { guidance by the teachers; testing and herewith } \\
\text { learning }\end{array}$ \\
\hline
\end{tabular}


Table II: Some characteristics of student-oriented policy and achievement-oriented policy






\begin{tabular}{|l|l|l|l|}
\hline Education forms & Technical subjects & Practice & General subjects \\
\hline General education & & & Dutch \\
Technical education & electronics & History \\
electronics & home economics & Maths \\
\hline social-technical & economics & Dutch \\
\hline $\begin{array}{l}\text { Vocational education } \\
\text { - woodwork }\end{array}$ & & History \\
- metalworking & moodwork & Maths \\
- caring & & metalworking & History \\
\hline
\end{tabular}



Table IV: Social characteristics of the interviewees and distribution of the population

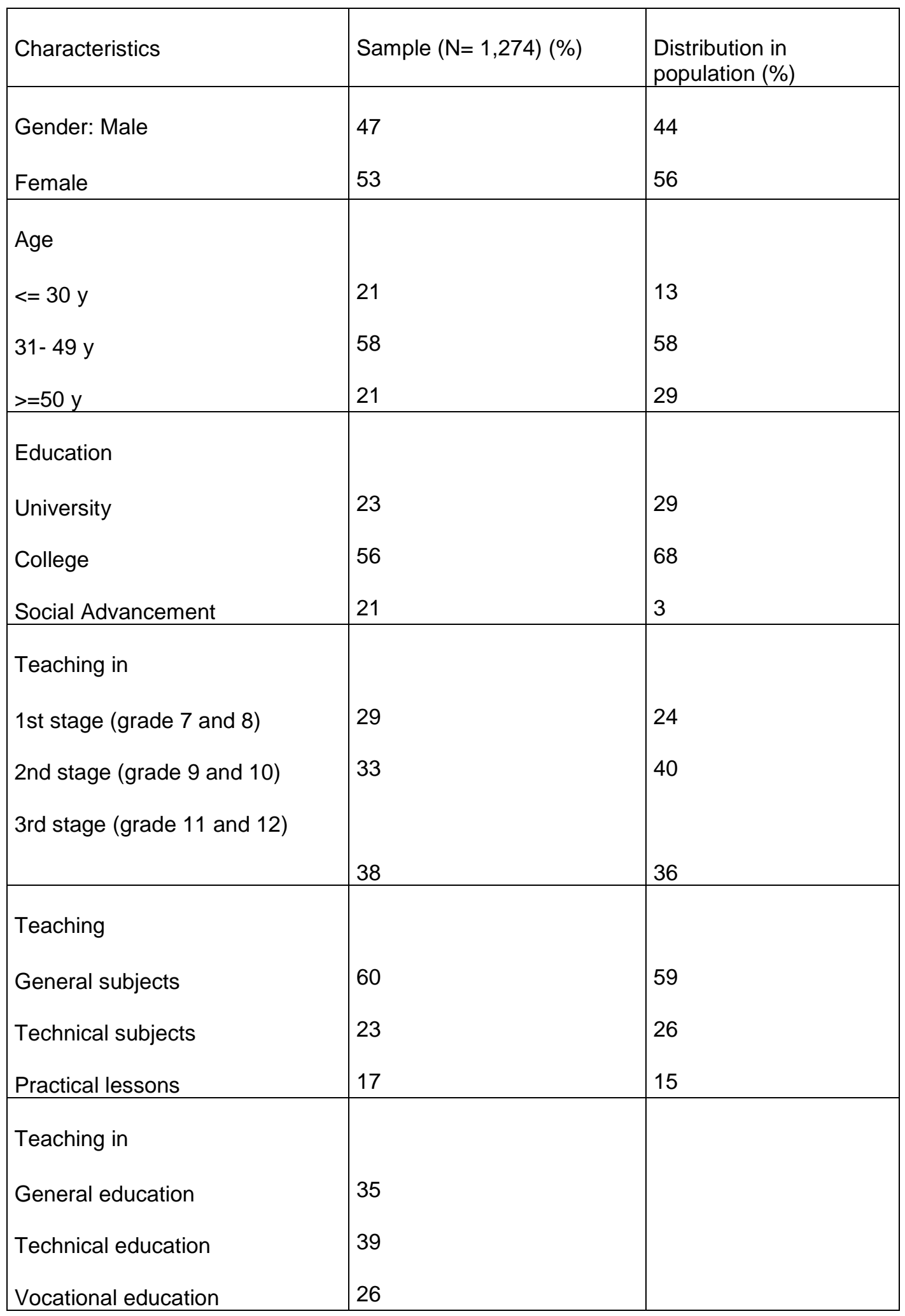


Table V: Attitude of teachers towards the assessment policy (means and \%)

\begin{tabular}{|l|c||c|c|c|c|c|c|}
\hline & & SD & $\begin{array}{c}\text { Totally } \\
\text { disagree }\end{array}$ & Disagree & Neutral & $\begin{array}{c}\text { Agree } \\
\begin{array}{c}\text { Totally } \\
\text { agree }\end{array}\end{array}$ \\
\cline { 2 - 7 } & Mean & & $\%$ & $\%$ & $\%$ & $\%$ & $\%$ \\
\hline $\begin{array}{l}\text { I know the vision of the school about } \\
\text { assessment }\end{array}$ & 4.10 & 0.79 & 0.7 & 3.2 & 50.5 & 13.3 & 32.4 \\
\hline $\begin{array}{l}\text { I support the vision of the school about } \\
\text { assessment }\end{array}$ & 3.68 & 0.89 & 1.2 & 9.0 & 46.7 & 26.7 & 16.5 \\
\hline $\begin{array}{l}\text { There are guidelines in the school for } \\
\text { assessment }\end{array}$ & 3.66 & 1.03 & 3.7 & 10.2 & 42.6 & 22.9 & 20.7 \\
\hline $\begin{array}{l}\text { There is deliberation among all teachers } \\
\text { of the same stage about assessment of } \\
\text { students }\end{array}$ & 3.47 & 1.20 & 5.6 & 20.2 & 33.1 & 18.4 & 22.8 \\
\hline $\begin{array}{l}\text { The head plays an important role in the } \\
\text { system of assessment of the school }\end{array}$ & 3.26 & 1.08 & 5.4 & 19.3 & 29.6 & 32.5 & 13.3 \\
\hline
\end{tabular}


Table VI: How frequently do teachers assess the following targets (\%)

\begin{tabular}{|c|l|c|c|c|c|}
\hline \multicolumn{2}{|l|}{} & Never & sometimes & often & always \\
\hline Assessment of & $\%$ & $\%$ & $\%$ & $\%$ \\
\hline $\mathrm{K}$ & I assess literally if the student knows some parts of the course & 15.1 & 52.6 & 25.9 & 6.4 \\
\hline $\mathrm{K}$ & I assess the knowledge of concepts and facts & 1 & 28.3 & 52.4 & 18.8 \\
\hline $\mathrm{C}$ & $\begin{array}{l}\text { I assess whether the student is able to see the links between various parts } \\
\text { of the course }\end{array}$ & 1 & 16.4 & 58.6 & 24.5 \\
\hline C & I assess whether the student is able to organise the information & 4.0 & 44.5 & 41.3 & 10.2 \\
\hline S & $\begin{array}{l}\text { When I assess I take into consideration the problem-solving capacity of } \\
\text { the student. }\end{array}$ & 2.0 & 27.6 & 50.0 & 20.3 \\
\hline S & I assess whether a student can apply a theory in new situations. & 1.4 & 23.0 & 54.7 & 21.0 \\
\hline S & $\begin{array}{l}\text { I assess students by asking them to illustrate the teaching content with } \\
\text { examples created by themselves. }\end{array}$ & $2 . .9$ & 35.0 & 48.6 & 13.5 \\
\hline A & I assess whether students can work accurately. & 1.8 & 15.5 & 48.1 & 34.7 \\
\hline A & I assess whether students work systematically when they solve problems. & 2.0 & 28.3 & 53.0 & 16.8 \\
\hline A & I assess whether students can reason critically. & 3.1 & 35.2 & 45.6 & 16.0 \\
\hline A & $\begin{array}{l}\text { When I assess students I take into account whether they work } \\
\text { independently. }\end{array}$ & 4.7 & 30.1 & 48.2 & 17.0 \\
\hline
\end{tabular}

$\mathrm{K}=\quad$ knowledge

$\mathrm{C}=$ comprehension

$\mathrm{S}=\quad$ skills

$\mathrm{A}=$ attitude 
Table VII: Pearson correlations between the opinion of teachers about assessment policy, student-oriented policy, and achievement-oriented policy

\begin{tabular}{|l|l|l|}
\hline Assessment Policy & Student-oriented Policy ${ }^{23}$ & Achievement-oriented Policy \\
\hline All teachers $(\mathrm{N}=1274)$ & $.43^{1}$ & $.12^{*^{1}}$ \\
\hline Teachers general education $(\mathrm{N}=407)$ & $.48^{2}$ & $.04^{2}$ \\
\hline Teachers vocational education $(\mathrm{N}=306)$ & $.37^{3}$ & $.16^{*^{3}}$ \\
\hline Teachers technical education $(\mathrm{N}=455)$ & $.41^{4}$ & $.16^{*^{4}}$ \\
\hline Teachers general subject $(\mathrm{N}=764)$ & $.40^{5}$ & $.03^{5}$ \\
\hline Teachers practical work $(\mathrm{N}=213)$ & $.39^{6}$ & $.21^{6}$ \\
\hline Teachers technical subject $(\mathrm{N}=292)$ & $.50^{* 7}$ & $.30^{* 7}$ \\
\hline$* \mathrm{p}<001$ & \\
\hline
\end{tabular}

*p $<.001$

${ }^{23}$ The same superscripts in this table show a significant difference $(p<.05)$ between two correlation coefficients. 
Table VIII: Pearson correlations between teachers' opinion about student-oriented and achievement-oriented policy, deliberation among teachers concerning assessment, deliberation among teachers and head concerning assessment, and discussions on meetings concerning assessment $^{24}$

\begin{tabular}{|c|c|c|c|c|c|c|}
\hline & \multicolumn{2}{|c|}{ Deliberation teachers } & \multicolumn{2}{|c|}{ Deliberation teacher head } & \multicolumn{2}{|c|}{ Discussion meetings } \\
\hline & $\begin{array}{l}\text { Student } \\
\text { oriented }\end{array}$ & $\begin{array}{l}\text { Achievement } \\
\text { oriented }\end{array}$ & $\begin{array}{l}\text { Student } \\
\text { oriented }\end{array}$ & $\begin{array}{l}\text { Achievement } \\
\text { oriented }\end{array}$ & $\begin{array}{l}\text { Student } \\
\text { oriented }\end{array}$ & $\begin{array}{l}\text { Achievement } \\
\text { oriented }\end{array}$ \\
\hline All teachers $(\mathrm{N}=1274)$ & $.35 * * 1$ & $.10 * * 1$ & $.34 * *^{2}$ & $.13 * *^{2}$ & $.35 * *^{3}$ & $.07 * *^{3}$ \\
\hline $\begin{array}{l}\text { Teachers general education }(\mathrm{N} \\
=407)\end{array}$ & $.38^{* * 4}$ & $-.10 * 4$ & $.37 * *^{5}$ & $-.03^{5}$ & $.39 * * 6$ & $-.04^{6}$ \\
\hline $\begin{array}{l}\text { Teachers vocational education } \\
(\mathrm{N}=306)\end{array}$ & $.39 * * 7$ & $.20 * * 7$ & $.40 * *^{8}$ & $.27 * * 8$ & $.33 * * 9$ & $.17 *^{9}$ \\
\hline $\begin{array}{l}\text { Teachers technical education } \\
(\mathrm{N}=455)\end{array}$ & $.36 * * 10$ & $.22 * * 10$ & $.25 * *$ & $.17 * *$ & $.34 * * 11$ & $.08^{11}$ \\
\hline $\begin{array}{l}\text { Teachers general subject }(\mathrm{N}= \\
764)\end{array}$ & $.36^{* * 12}$ & $.03^{12}$ & $.35^{* * 13}$ & $.05^{13}$ & $.38 * * *^{14}$ & $.07 *^{14}$ \\
\hline $\begin{array}{l}\text { Teachers practical work }(\mathrm{N}= \\
213)\end{array}$ & $.29 * *$ & $.25^{* *}$ & $.31 * *$ & $.35 * *$ & $.27 * * 15$ & $.11^{15}$ \\
\hline $\begin{array}{l}\text { Teachers technical subject }(\mathrm{N}= \\
292)\end{array}$ & $.34 * *$ & $.25^{* *}$ & $.32 * *$ & $.19^{* *}$ & $.34 * * 16$ & $.05^{16}$ \\
\hline
\end{tabular}

$* * \mathrm{p}<.001$

$* \mathrm{p}<.05$

${ }^{24}$ The same superscripts in this table show a significant difference $(p<.05)$ between two correlation coefficients. 
Figure 1: Structure of Flemish Secondary Education

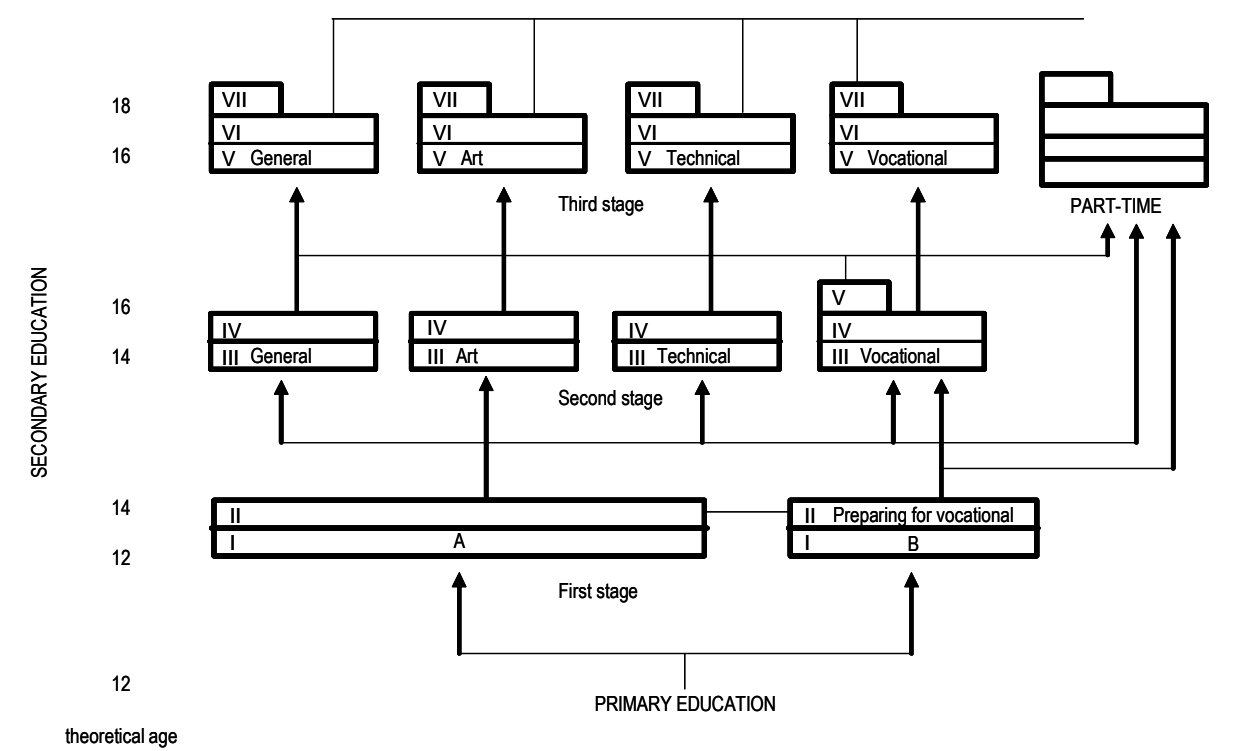


Abstract

This paper describes the relationship between assessment practices and assessment policy and between general policy and assessment policy as teachers experience it in Belgian secondary schools in Flanders. Since the attainment targets of general, technical, and vocational education are different, this research explored whether teachers in the three forms of secondary education define these relationships differently. Our results enable us to argue that teachers in vocational education appear to have developed a different kind of assessment culture from the others, but the majority of the teachers still live in a testing culture, not in an assessment culture. Teachers in vocational education experience more student-oriented school policies than do teachers of technical education, but they do not differ from the teachers in general education. As far as achievement-oriented policy is concerned, there is a difference between teachers in vocational schools and the others. Nevertheless, quite a few teachers in the three forms of education that perceive a student-oriented policy perceive also an assessment policy, which is not the case for the teachers who perceive an achievement-oriented policy. 
Jef C. Verhoeven is Professor of Sociology at the KU Leuven in Belgium and Head of the Centre for Sociology of Education of the same university. He has published in the fields of theoretical sociology and sociology of education. Recently, he has conducted several projects on secondary education in Belgium (amongst others, about human resource management in secondary schools and the evaluation of an equal opportunity project in Belgium), some of them in collaboration with Geert Devos. He has published several books and articles in journals such as The European Journal of Education, The Journal of Education Policy, Educational Management and Administration, Research on Language and Social Interaction, Teacher Development, Studies in Higher Education. Jef C. Verhoeven, Centre for Sociology of Education, University of Leuven, E. Van Evenstraat 2b, 3000 Leuven, Belgium

\section{jef.verhoeven@soc.kuleuven.ac.be}

Geert Devos is an assistant professor at the Vlerick Leuven Ghent Management School in Belgium and at the University of Ghent in Belgium. His research interests are school organisation, change management and organisational behaviour. His most recent publication is 'School Self-Evaluation - Conditions and Caveats: The Case of Secondary Schools' (with J.C. Verhoeven) in Educational Management and Administration (2003). Geert Devos, Vlerick Leuven Ghent Management School, Reep 1, 9000 Ghent, Belgium, 
Geert.Devos@vlerick.be 